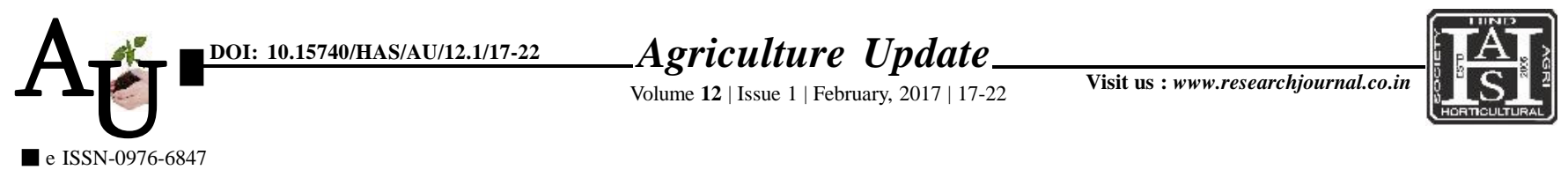

\title{
Research Article: Socio-economic analysis of organic and non-organic vegetable growers in Belgaum district of Karnataka
}

VINOD NAIK, L.B. KUNNAL AND K.R. NETHRAYINI

SUMMARY : The present study was conducted in Belgaum district of North Karnataka as there are large numbers of farmers practicing the organic cultivation of vegetables. 30 farmers each practicing Article Chronicle: Received : 15.11.2016; Revised : 05.12.2016; Accepted : 13.12.2016

Key Words: Organic farms, Nonorganic farms, B:C, Garrett ranking

Author for correspondence :

\section{VINOD NAIK}

Department of Agricultural Economics, University of Agricultural Sciences, DHARWAD (KARNATAKA) INDIA

Email:naikvinod00@ gmail.com

See end of the article for authors' affiliations organic cultivation of tomato and chilli and 30 farmers each practicing non-organic cultivation of tomato and chilli spread over the district of Belgaum were selected randomly for the study. The collected data were analysed using tabular presentation method and Garrett ranking technique. The study revealed that, majority of the sample farmers expressed increasing return from organic vegetables as the reason for shifting over to organic cultivation of vegetables from non-organic cultivation. The estimated per acre cost of cultivation of tomato and chilli on organic farms was high as compared to non-organic farms whereas, the net returns was high in the case of organic farms as compared to non-organic farms. The major problems faced by the sample farmers were non-availability of labour and high commission charges.

How to cite this article : Naik, Vinod, Kunnal, L.B. and Nethrayini, K.R. (2017). Socio-economic analysis of organic and non-organic vegetable growers in Belgaum district of Karnataka. Agric. Update, 12(1): 17-22; DOI : 10.15740/HAS/AU/12.1/17-22. 